\title{
Risk Management Scenarios for Investment Program Delays in the Polish Power Industry
}

\author{
Stanisław Tokarski ${ }^{1}$ (D), Małgorzata Magdziarczyk ${ }^{2}$ and Adam Smoliński ${ }^{1, *(D)}$ \\ 1 Central Mining Institute, Plac Gwarków 1, 40-166 Katowice, Poland; stokarski@gig.eu \\ 2 Department of Economics, Finance, Regional and International Research, Opole University of Technology, \\ ul. Luboszycka 7, 45-036 Opole, Poland; m.magdziarczyk@po.edu.pl \\ * Correspondence: smolin@gig.katowice.pl; Tel.: +48-322-592-252
}

Citation: Tokarski, S.; Magdziarczyk, M.; Smoliński, A. Risk Management Scenarios for Investment Program Delays in the Polish Power Industry. Energies 2021, 14, 5210. https:// doi.org/10.3390/en14165210

Academic Editors: Danijela Miloš Sprčić and Hrvoje Pandžić

Received: 16 July 2021

Accepted: 20 August 2021

Published: 23 August 2021

Publisher's Note: MDPI stays neutral with regard to jurisdictional claims in published maps and institutional affiliations.

Copyright: (C) 2021 by the authors. Licensee MDPI, Basel, Switzerland. This article is an open access article distributed under the terms and conditions of the Creative Commons Attribution (CC BY) license (https:/ / creativecommons.org/licenses/by/ $4.0 /)$.

\begin{abstract}
The introduction of the Green Deal in 2019 by the European Commission poses a significant challenge for EU member states whose power generation is based primarily on fossil fuels. In Poland, nearly $80 \%$ of the electricity is produced from fossil fuels. This paper presents an analysis of the risks related to the delays in the accomplishment of investment programs in the Polish power industry. Three scenarios were prepared for balancing the deficiency of about $3 \mathrm{GW}$ of power and 20 TWh of electricity in the national power grid in the years 2031-2040, which may emerge as a result of the delayed accomplishment of investment programs, particularly in nuclear energy. The first scenario presents a variant entailing the rapid phasing out of coal and the replacement of the decommissioned power units with new gas-powered units, where the missing power volume would be partially balanced by import, and partially through gas-based production in the new power units. The second scenario assumes that the missing power would be balanced by retaining the existing, older coal-powered units, whereas the required electricity would be compensated by import. The third scenario involves the production of the missing volume of electricity using coal with $\mathrm{CO}_{2}$ capture in existing or new coal-powered units.
\end{abstract}

Keywords: energy policy; forecast; just transition; risk analysis

\section{Introduction}

The Polish electric power system is part of the European system in terms of both physical connections and the organisation of the energy market [1,2]. From a technical perspective, it is linked to the West European system (the continental market) with synchronous connections through high-voltage power lines to Germany, Czechia and Slovakia, and with asynchronous connections to Sweden and Lithuania (direct current connections) $[3,4]$. There is also a connection with the Ukrainian system, which operates independently of the common European system $[5,6]$. According to European regulations, it is recommended for cross-border connections to provide the physical capacity for transmitting $15 \%$ of the power required for the interconnected system by 2030 . From the economic perspective, the Polish electric power market has been operating together with the European market for almost 20 years. The free exchange of electricity is one of the key foundations of the reform based on market coupling. According to EU Market Regulation 2019/943 [7], which is part of the Clean Energy for All Europeans [8] regulation package adopted in 2019, the cross-border connections ought to be made available for market purposes for up to $70 \%$ of their technical transmission capacity starting in 2020 . The construction of a uniform European electric power market will enter its decisive stage in 2021, and it will enable cross-border power trading on intraday and day-ahead markets as well as the trade balancing of the system.

According to the annual URE data [9], in 2019, the power installed in power plants operating as part of the national power system (KSE) was 46,799 MW, 70\% of which comprised brown- and hard-coal-fired sources. The power generated by renewable energy 
sources exceeded $20 \%$ of the total power in the KSE. By the end of 2019, the power generated from renewables was 9.5 GW. The final large-scale hard-coal-fired power unit with a power of $910 \mathrm{MW}$ was brought into operation in 2020 in Jaworzno. The completion of the final brown-coal-fired power unit with a power of $500 \mathrm{MW}$ is planned for 2021 in Turów. The maximum power demand in the KSE was 26,500 MW in the winter season, which constituted a slight annual increase. According to the data of the European Network of Transmission System Operators for Electricity [10], in January 2021, the power installed in the KSE increased by about $2.5 \mathrm{GW}$, reaching a total installed capacity of about $49.3 \mathrm{GW}$. This value was also influenced by the $3.8 \mathrm{GW}$ increase from renewables and $1.3 \mathrm{GW}$ decrease from conventional power sources. An increase in installed power (from $430 \mathrm{MW}$ to nearly $3.5 \mathrm{GW}$ ) was observed in photovoltaic sources between the year 2019 and January 2021. The total installed renewable power by the end of 2020 was nearly $12.5 \mathrm{GW}$ and exceeded $25 \%$ of the total KSE power.

The electricity production in 2019 was $158.8 \mathrm{TWh}$, which was lower by $3.9 \%$ compared to the prior year. The contribution of coal to electricity production was $73.6 \%$, which constituted an annual decrease of $4.8 \%[11,12]$. A horizontal trend can be observed in the early part of the last 10 years, meaning that the power produced in the country remained at a similar level, whereas the most recent years exhibit a considerable drop. Polska Grupa Energetyczna (PGE) had the greatest contribution to power production in 2019, at a level of $40.6 \%$. The provisional power production in 2020 was $152.3 \mathrm{TWh}$, which was lower by $4.1 \%$ compared to the prior year. The greatest percentage production increase was observed in photovoltaic sources, which contributed over 1.6 TWh to the grid.

The electricity demand in 2019 was 169.4 TWh, which constituted a decrease of $0.9 \%$ compared to the prior year. This means that economic growth occurred with no increase in electricity demand. An increasing average annual trend of $1.1 \%$ can be observed for energy use over the last 10 years. The balance of energy production and demand in 2019 reveals that import is increasing relative to export. The import reached a level of $10.6 \mathrm{TWh}$, which was the highest in history. The predominance of import over export is primarily influenced by economic factors, namely the differences in energy prices. In 2020, the electricity demand decreased to 165.5 TWh, i.e., by $2.3 \%$. This decrease was primarily influenced by the slowdown in the economy as a result of the COVID-19 pandemic. In the second quarter of 2020, the decrease in the energy demand exceeded even 5\%, though provisional data for 2020 indicate a drop of nearly $2.3 \%$ at a GDP decrease of $2.8 \%$ over the entire year. In 2020, the import of electricity into Poland exhibited an increase, with a net value of 13.2 TWh. This constitutes another record high level of energy import into Poland.

Clear trends can be observed in both Poland and the rest of Europe for a transition of the economy, including the energy sector, towards a zero-carbon system, together with the linking of the European recovery fund with green investments [13]. The restructuring of the power production from a traditional, coal-based system into a renewable one, based on fuel gas during the transition period, must influence the increase in energy prices. In the case of Poland, it is necessary to mention the three price-determining factors that will shape the energy market in successive time periods:

1. A power market mechanism and a power capacity fee that will be borne by energy users were introduced on 1 January 2021 (the cost of the power market in 2021 is about 1.2 billion EUR).

2. The price of carbon dioxide emission permits exceeded a level of 50 EUR per ton in 2021.

3. The government adopted an Energy Policy for 2040, which assumes a green energy transition through measures such as the construction of offshore wind farms, whose reference price for auctions was determined at a level of 301.5 PLN/MWh (about 70 EUR/MWh).

The transition of the electric power system concerns both the grid infrastructure (high voltage transmission networks and distribution networks) and the power production sources. Modernisation and investment action, according to the KSE Development Plan [14] 
published in 2020, should be undertaken in the areas of power production, transmission and distribution. In terms of network-related areas, the scope of the investment encompasses:

- $\quad$ increasing the power of cross-border connections and removing bottlenecks in the KSE.

- $\quad$ introducing new power production sources, including offshore wind farms.

- $\quad$ restructuring the distribution networks from the perspective of controlling prosumer sources and microgeneration.

- $\quad$ energy storage, including for the purpose of providing energy quality assurance.

- $\quad$ smart network measurement and management.

The Polish electric power system, connected by physical and market means with the European system, will undergo further integration. Based on Regulation 2019/943, constituting a part of [8], starting on 1 January 2021 member states are obliged to share their maximum available cross-border transmission capacity, but this must be no less than $70 \%$ of the total capacity. States that are unable to fulfil this condition may present an action plan for achieving such a level of transmission capacity and extend the time limit until the end of 2025. Poland has already presented an investment and modernisation plan within this scope. Furthermore, as part of the system development planning, Polskie Sieci Elektroenergetyczne (PSE) have prepared a plan to increase the power of the connections at the borders with countries such as Germany, Czechia, Slovakia and Lithuania, as well as to establish new connections with Germany and Denmark, in order to assure that the physical power flows could correspond to the trade contracts concluded on the European market.

Power distribution companies must perform a restructuring of the system, which was established to provide electricity from the producer to the user. In the new power system, it will be necessary to effectively manage power flows from prosumers, local clusters and communities, and small-scale dispersed sources to the grid, and to provide it from baseload sources in cases of power shortages. This requires investments to improve the network infrastructure in new dispersed source connector locations and control systems, and to expand the measuring and IT infrastructure. The power transmission and distribution service are regulated, and its price is subject to the approval of the President of the Energy Regulatory Office (Urzad Regulacji Energetyki, URE). The funding for expanding the distribution and transmission network and the cross-border connections are secured from tariff revenue and European funds.

The power for the KSE is generated in baseload, industrial and dispersed power plants. In 2020 , about $92 \%$ of the energy was generated by national sources. According to the Polish Energy Policy for 2040, the establishment of what is practically a new, low-carbon power production system is planned for the next 20 years (dispersed and centrally dispatched sources). Some of the plans included in the Policy entail the commissioning of the first nuclear power unit in 2033 and supporting the power grid with nearly $6 \mathrm{GW}$ of power provided by offshore wind farms. The program is extremely ambitious and demanding; therefore, the risk of delays in its implementation needs to be considered.

The purpose of this paper is to analyse the risks related to the delays in the accomplishment of investment programs in the Polish power industry. The article presents three possible scenarios (alternatives) for balancing the deficiency of about $3 \mathrm{GW}$ of power and 20 TWh of electricity in the national power grid in the years 2031-2040, which may emerge as a result of the delayed accomplishment of investment programs, particularly in nuclear energy. The first scenario, which assumes the rapid phasing out of coal and the replacement of the decommissioned power units with new gas-powered units, where the missing power volume would be partially balanced by import, and partially through gas-based production in the new power units, may have the lowest influence on the final increase in energy prices. The second scenario assumes that the missing power would be balanced by retaining the existing, older coal-powered units, whereas the required electricity would be compensated by import. The third scenario, on the other hand, involves the production of the missing volume of electricity using coal with $\mathrm{CO}_{2}$ capture in existing or new coal-powered units. 


\section{Materials and Methods}

The vast majority of the baseload power plants, based on brown and hard coal, were built before the year 1980 and have already exceeded their planned operation time [15]. Due to broad-scale modernisation programs, these power plants were equipped with air protection measures and their efficiency was improved as well. After the year 2000, six $200 \mathrm{MW}$-class power units were restored in Turów, $460 \mathrm{MW}$-class power units were established in Patnów and Łagisza, while four 1000 MW-class units were brought into operation in Kozienice, Opole and Jaworzno in 2017-2020. The investment in the final 500 MW coal-powered unit in Turów is expected to be completed in 2021. Apart from the investments in baseload power units, the accomplishment of numerous investment projects in renewable sources has also been undertaken since the early 2000s, including biomass combustion in the initial period, and onshore wind farms later on. However, 2020 should be considered a record year in terms of the investments in photovoltaic sources (power increase of $3 \mathrm{GW}$ ). Such a fuel and age characteristic of the Polish power plants presents a unique opportunity to replace the spent coal-fired plants with new, low-carbon and zero-carbon sources, but it also poses a number of practical challenges for the existing units. New energy sources with intermittent power generation, renewables in particular, raise the necessity to maintain reserve grid capacity by baseload power plants with continual power generation.

The primary challenges faced by the operators of Polish power plants include:

1. Retrofitting the existing coal-fired plants to fulfil the emission requirements.

2. Modernisation from the perspective of reserve capacity and operational flexibility for renewable power generation in the KSE.

3. Investments in new power production, including gas-powered units.

4. The Green Deal and the necessity for energy companies to undergo transformation.

5. The European policy in terms of climate and energy.

6. The program of the Polish Energy Policy for 2040.

The Polish Energy Policy for 2040 is intended to act as a framework for the major energy transition aimed at achieving climate neutrality in 2050 or later. It is based on three pillars:

- fair transition;

- a zero-carbon electric power system;

- good air quality.

The Polish Energy Policy for 2040 was developed to be consistent with the Strategy for Responsible Development [16] of 14 February 2016, and the European Green Deal, which assumes that the European economy will achieve climate neutrality by 2050 . Table 1 presents the goals of the Polish Energy Policy for 2040 relative to the objectives of the European climate and energy policy. Poland presented the final version of the National Plan for Energy and Climate [17] in 2020 to define the Polish contribution to the accomplishment of European goals according to the 2019 principles of Energy Union management. The document presented the goals and actions intended to support the achievement of the European goals of 2014, i.e., the objectives that were finally agreed upon in 2019 and included in [8], in what is known as the Winter Package. In this research work, the methods of study the long-term prospects of the fuel and energy system were presented. The aim of the study of the prospects of the fuel and energy system was to estimate the paths of its development or to determine its future condition based on the economic requirements, resource and environmental constraints. 
Table 1. Goals of the Polish Energy Policy for 2040 relative to the objectives of the European climate and energy policy.

\begin{tabular}{|c|c|c|c|c|c|}
\hline $\begin{array}{c}\text { European-Level } \\
\text { Goals }\end{array}$ & $\begin{array}{c}\text { 1st Climate } \\
\text { Package, } 2009\end{array}$ & $\begin{array}{l}\text { 2nd Climate } \\
\text { Package, } 2014\end{array}$ & $\begin{array}{c}\text { 2nd Climate } \\
\text { Package, Final } \\
\text { Goals of } 2019\end{array}$ & $\begin{array}{l}\text { Conclusions of } \\
\text { the Council, } \\
\text { December } 2020\end{array}$ & $\begin{array}{l}\text { Polish Goals per } \\
\text { PEP } 2040\end{array}$ \\
\hline $\mathrm{CO}_{2}$ reduction & $20 \%$ & $40 \%$ & $40 \%$ & $55 \%$ & $30 \%$ \\
\hline $\begin{array}{c}\text { Renewable energy in } \\
\text { total energy } \\
\text { consumption }\end{array}$ & $20 \%$ & $27 \%$ & $32 \%$ & $32 \%$ & $23 \%$ \\
\hline Energy efficiency & $20 \%$ & $27 \%$ & $32.5 \%$ & $32.5 \%$ & $23 \%$ \\
\hline
\end{tabular}

As can be seen in Table 1, the Polish declarations pertaining to the European contribution exhibit major negative differences compared to the general goals. Admittedly, the European goal does not impose an obligation to contribute equally to its achievement, as the starting points for various countries are different. Nevertheless, the Polish contribution to the major restructuring of the European economy leaves no room for delayed reforms and their accomplishment at an individual pace. Falling behind other economies will always result in adverse effects for the national economy and in losing the benefits associated with the spearheading of new trends. Apart from the goals as outlined in Table 1, pertaining to carbon reduction, increased renewable energy use and improved energy efficiency, the primary factors for implementing the Policy were defined as limiting the use of coal for electricity generation to no more than $56 \%$ of the total electricity generated in 2030 , and introducing nuclear power in 2033.

EU countries exhibit two opposite approaches to the issue of nuclear power development. On the one hand, Germany decided to decommission its nuclear power plants and permanently halt the development of this technology, whereas the neighbouring France is formulating successful long-term plans for a 50\% contribution of nuclear energy in its energy mix. Poland is preparing to establish its first nuclear power unit. Investments in nuclear power are burdened by numerous technological risks and limitations related to potential disasters, which increase the safety requirements. The nuclear projects currently being carried out in Europe and worldwide are unpredictable with regard to the schedule and budget (the originally planned capital investment can be exceeded even thrice). For example, the construction of the third nuclear power unit in Olkiluoto in Finland was commenced in 2005, but it may finally be brought into operation in 2021 (i.e., after 16 years), whereas its cost has reached nearly 8 billion EUR, while a similar situation can also be observed in the French Flamanville project [18]. In January 2020, the French government announced that it would delay the decision pertaining to the establishment of new nuclear power plants until 2022. In the case of the first Polish nuclear project, no decisions have yet been taken as to its location, and the legal formula of the entity expected to conduct the investment has yet to be defined. The strategic partner and the financing scheme also remain unknown. Currently, the only known financing scheme is the contract for difference, which was notified by the British for the Hinkley Point project [19].

\section{Results and Discussion}

In 2021, the European law concerning emissions originating from the power industry will be adapted to a new carbon dioxide emission goal of $55 \%$ by 2030 , ultimately followed by the climate neutrality of the European economy by 2050. The new regulations will replace those that were issued as part of the Winter Package in 2019. It can be expected that the prices of carbon dioxide emission permits will remain high in the coming future. The safety of the electric power system, understood as the capacity to provide enough power in extreme situations, requires the preparation of alternative scenarios for the basic ones defined in the Polish Energy Policy for 2040. While there is no denying that the nuclear-and-renewable power option, with transition fuel in the form of gas, appears to 
be the correct solution for the Polish economy, the following issues must nevertheless be brought up for discussion:

1. The European energy market will undergo further integration in the coming yearsthe increase in the cross-border connection flow capacity and electric energy volumes on all types of trading platforms should be expected in particular. According to the document [14], the cross-border connection flow capacity is expected to increase from about $1.8 \mathrm{GW}$ to about $4 \mathrm{GW}$ after 2025. This entails the potential increase in the electric energy transmission capacity to about 30 TWh per year. The import of electricity into Poland may constitute a significant option in the alternative scenarios.

2. The ambitious investment program for power generation, which assumes the introduction of about $31 \mathrm{GW}$ of power by 2035, must factor in not only the risks related to securing the funding sources and work performance capacity, but also the risk of missing the deadline for the completion of the program. The current practice for accomplishing major investments, and the typically 5-year-long period of production process familiarisation and optimisation, suggests a significant risk of delayed completion, particularly for the nuclear program. It is necessary to identify alternative directions of electricity and power delivery to the national system.

3. According to the PSE survey [14], about 3.2 GW of stable power will be brought into operation by 2030, including a coal-powered unit in Ostrołeka (currently, this project has been phased down). Assuming that the risk of investment schedule delay by about $5-10$ years comes to pass, it will be imperative to provide about $3 \mathrm{GW}$ of stable power and about 20 TWh of electricity per year for the duration of this period.

When analysing all the risks related to the delayed investments in the Polish power industry, three possible alternative scenarios for the power sector must be considered:

1. The renewable energy scenario with increased import and gas as a transition fuel;

2. The renewable energy scenario with increased import but no increased role of gas in power generation;

3. The renewable energy scenario with coal as a transition fuel (technologies combined with CCUS).

The renewable energy scenario with increased import and gas as a transition fuel assumes that over the period of 2031-2040, instead of nuclear power, an annual average of $3 \mathrm{GW}$ of power with continual generation capacity will be replaced by $700 \mathrm{MW}$ gas and steam-powered units. Any potential delays in the offshore wind farm program will have no influence on the stability of the electric power system. The missing electricity volume will be balanced by import through the planned expansion of cross-border connections. Coal-fired power plants will be phased out of the energy market starting in 2026. It is assumed that about 3-5 GW of hard coal power, provided by $200 \mathrm{MW}$ power units, will have an essential role as a KSE strategic reserve after 2035, following the adaptation of the power units for flexible operation in the system. These units can be transferred to the planned Energy Security Agency and activated by PSE in the event of power shortages in the system. The scenario assumes an increase in gas-fired power use from about $3 \mathrm{GW}$ (PEP 2040 data) to about $6 \mathrm{GW}$ in 2035, with an additional annual production of about 10-15 TWh (market competition with import). The factor for the rising electric power production costs is related to the emission generation, and the forecast increases in fuel gas prices compared to imported green energy. The following assumptions were adopted for the scenario:

- $\quad$ Establishing 4-5700 MW gas-powered units in place of the existing coal-fired power plants, with a total power of about $3 \mathrm{GW}$-Capex of about 2 billion EUR;

- $\quad$ An assumed operational period of 2031-2040, then part of the KSE strategic reserve after 2040;

- Production of about 10-15 TWh per year in the 2031-2040 period;

- $\quad$ Demand for fuel gas-about 1.5-2 billion $\mathrm{m}^{3}$; 
- Electric power production cost increase resulting from forecast fuel gas and emission permit prices-about $20 \mathrm{EUR} / \mathrm{MWh}$.

Advantages of the proposed scenario include the significant decrease in carbon dioxide emissions during electricity production, the short investment cycle and the relatively minor capital investment for the delayed nuclear program completion risk management. The primary disadvantages involve the necessity to provide additional gas volumes, and the increased dependence on imported energy resources.

The renewable energy scenario with increased import but no increased role of gas in power generation assumes the accomplishment of an ambitious renewable power generation program and the increased import of electric energy over the period of 2031-2040. It is also assumed that the delayed introduction of nuclear power will be balanced by means of existing coal-powered units during the transition period, particularly $1000 \mathrm{MW}$ power units, and modernised older units, providing 5-8 GW of power. Given the high emission permit costs, the coal-powered units will be primarily providing power to the system. Electric energy production will be limited to a level resulting from concluded trade agreements (the assumed average annual production would be no greater than $10 \mathrm{TWh}$ ). The factor for the rising electric power production costs is related to the emission generation (power units without CCUS) compared to imported green energy. The following assumptions were adopted for the scenario:

- Investment in the modernisation of 12-15 $200 \mathrm{MW}$ coal-powered units, according to the goals of the 200 plus program- 0.5 billion EUR; additional investment in modernisation from the perspective of new BAT requirements-about 0.5 billion EUR. Up to about 1 billion EUR in total;

- Annual electricity production as half of the missing volume, i.e., 10 TWh;

- Additional demand for hard coal—about 5 million Mg per year;

- Increased electricity production cost resulting from emission permits-about 50 EUR/MWh.

Advantages of the proposed scenario include the low capital investment required to maintain the power unit operation, easing the hard coal extraction limitation process, and greater independence from imported energy resources. The primary disadvantages involve higher electric energy production emission rates, the delayed energy transition process and the greater electricity production costs.

The renewable energy scenario with coal as a transition fuel (technologies combined with CCUS) assumes the accomplishment of an ambitious investment program in renewable sources, just as specified in the Polish Energy Policy for 2040 [20,21]. Given the emergence of the high prices for carbon dioxide emission permits (cost exceeding $50 \mathrm{EUR} /$ ton of $\mathrm{CO}_{2}$, March 2021), the technology of coal combustion and gasification with carbon dioxide capture and storage should be considered once again as an investment option for the years 2031-2060 [22,23]. In the first stage, i.e., until 2040, this option will be considered as an alternative scenario for the delay in the nuclear program accomplishment by $5-10$ years. After 2040, the implementation of this scenario would entail the lower contribution of gas to electric energy production. The following assumptions were adopted for the scenario:

- $\quad$ Equipping the three existing $1000 \mathrm{MW}$ power units, CCS ready, with carbon dioxide capture and compression installations. Capital investment of about 2.5 billion EUR. Furthermore, the Program for Silesia, which is undergoing notification at the European Commission, assumes the investment in an IGCC power unit, with about $300 \mathrm{MW}$ of power, with a carbon dioxide capture system. The estimated capital investment per unit is about 1 billion EUR. The expenses for the carbon dioxide transport and storage infrastructure would have to be incurred by an operator appointed by the state. Producers would be obligated to transport the compressed carbon dioxide to the power plant perimeter. It should be assumed, based on international experience, that at an emission permit price of about 50 EUR per unit, this sum should be equal to 
the costs of the carbon capture, transport and storage. The factor for the rising electric power production costs is related to the necessity to incur the expenses of carbon dioxide capture, transport and storage.

- Electricity production-about 20 TWh per year;

- Additional demand for coal—about 10 million Mg per year;

- Electric energy production cost, increased by about 50 EUR for the capture, transport and storage of $1 \mathrm{Mg}$ of $\mathrm{CO}_{2}$-about $50 \mathrm{EUR} / \mathrm{MWh}$.

Advantages of the proposed scenario include primarily the easing of the hard coal extraction limitation process, and greater independence from imported energy resources. The primary disadvantages involve greater capital investment, the absence of infrastructure for carbon dioxide transport and storage, no legal regulations concerning the storage of carbon dioxide in geological formations and including the $\mathrm{CO}_{2}$ capture and storage costs in the price of electricity.

Table 2 presents a comparison of the alternative scenario variables in terms of the capital investment and the influence on the unit costs of electric energy production.

Table 2. Comparison of alternative scenario variables, including the capital investment and the influence on the unit costs of additional electric energy production.

\begin{tabular}{|c|c|c|c|c|}
\hline No. & Variables & $\begin{array}{c}\text { Renewables + Import + } \\
\text { Gas Scenario }\end{array}$ & $\begin{array}{c}\text { Renewables + Import } \\
\text { Scenario }\end{array}$ & $\begin{array}{c}\text { Renewables + Coal CCS } \\
\text { Scenario }\end{array}$ \\
\hline 1 & Capital investment & 2 billion EUR & 1 billion EUR & 3.5 billion EUR \\
\hline 2 & $\begin{array}{l}\text { Electric energy } \\
\text { production/year }\end{array}$ & 10-15 TWh & $10 \mathrm{TWh}$ & $20 \mathrm{TWh}$ \\
\hline 3 & Fuel demand & 1.5-2 billion $\mathrm{m}^{3}$, gas & 5 million $\mathrm{Mg}$, coal & 10 million $\mathrm{Mg}$, coal \\
\hline 4 & $\begin{array}{l}\text { Influence on electric energy } \\
\text { production costs }\end{array}$ & $\begin{array}{l}\text { increase by about } \\
20 \mathrm{EUR} / \mathrm{MWh}\end{array}$ & $\begin{array}{l}\text { increase by about } \\
50 \mathrm{EUR} / \mathrm{MWh}\end{array}$ & $\begin{array}{l}\text { increase by about } \\
50 \mathrm{EUR} / \mathrm{MWh}\end{array}$ \\
\hline 5 & Energy independence & * & $* * *$ & $* * * * *$ \\
\hline
\end{tabular}

The first scenario, which assumes the rapid phasing out of coal and the replacement of the decommissioned power units with new gas-powered units, where the missing power volume would be partially balanced by import, and partially through gas-based production in the new power units, may have the lowest influence on the final increase in energy prices. It presents a risk concerning the availability of an additional 1.5-2 billion $\mathrm{m} 3$ of gas, and the actual shifts in gas prices (the Polish Energy Policy for 2040 assumes an increase in gas prices of only $11 \%$ in the $2030-2040$ period). The second scenario, which assumes that the missing $3 \mathrm{GW}$ of power would be balanced by maintaining the existing older coal-powered units, while the required electric energy would be compensated by import, presents the most inexpensive investment, but the costs of energy produced using coal need to include the current price for the $\mathrm{CO}_{2}$ emission permits. The high electricity production emission rates will also be retained in this variant. The third variant, which assumes electricity production using coal with $\mathrm{CO}_{2}$ capture in new power units based on combustion and gasification technology, presents the absolutely most expensive investment, and it must also factor in the increase in energy production costs related to the carbon capture and storage costs. A reference factor of 50 EUR per MWh was adopted based on a review of international solutions and own calculations. At the same time, this variant also provides zero-carbon energy production while retaining coal as a resource, and it offers the greatest independence from imported energy resources.

\section{Conclusions}

The Green Deal-based Polish Energy Policy for 2040 assumes the total restructuring of the electric energy production system over the course of the next 20 years. Coal-based power production is to be replaced with an energy mix consisting of renewable sources 
and nuclear power, with natural gas as the transition fuel. When analysing the scope of the investment program and its schedule ( $31 \mathrm{GW}$ of new power sources must be introduced by 2035, including two nuclear power units), it is necessary to consider the risk of a 5-10year-long delay in the completion of the program and to undertake the action necessary to manage this risk. Based on the conducted investigation, it was concluded that:

1. Restructuring the Polish power production sector in the direction of renewable, lowcarbon and zero-carbon sources in the shortest possible time is in the interest of both the economy and the individual users.

2. Particular concerns are raised by the feasibility of the nuclear program, which assumes that the first nuclear power unit would be brought into operation in as little as 12 years. Considering the lack of siting considerations, the decisions as to the technology, the partnership, the financing mechanisms (notification required at the European Commission), the funding sources, as well as the necessity to conduct public procurement procedures, the deadline for bringing the first nuclear power units into operation ought to be extended by at least 5 to 10 years.

3. Given the necessity to synchronise the coal-powered unit decommissioning program with the introduction of new power units (ensuring system operation stability at limited cross-border connection capacity), it is necessary to prepare alternative scenarios for the years 2031-2040, which would define the details concerning the supply of about $3 \mathrm{GW}$ of power and about 20 TWh of electric energy per year.

4. Based on the conducted scenario-based analysis, the adoption of variant I (renewables + import + gas) or II (renewables + import), supported by coal-fired power plants acting as power providers to the system, should be taken into consideration as an optimal choice from the perspective of power production costs and emission rates.

5. In the event of the emergence of high prices for $\mathrm{CO}_{2}$ emission permits (PEP 2040 assumes a level of $30 \mathrm{EUR}$, whereas the price projected for 2030 by the EC is $54 \mathrm{EUR}$, while the current price for the permits has already exceeded 50 EUR), the use of combustion technologies in existing power plants integrated with CCS and coal gasification/CCS systems should be considered once again as a zero-carbon technology for the transition period until 2060, which would replace the partially imported fuel gas.

Author Contributions: Conceptualization, S.T., M.M. and A.S.; methodology, S.T., M.M. and A.S. All authors have read and agreed to the published version of the manuscript.

Funding: This research received no external funding.

Institutional Review Board Statement: Not applicable.

Informed Consent Statement: Not applicable.

Data Availability Statement: Not applicable.

Conflicts of Interest: The authors declare no conflict of interest.

\section{References}

1. Simla, T.; Stanek, W. Influence of the wind energy sector on thermal power plants in the Polish energy system. Renew. Energy 2020, 161, 928-938. [CrossRef]

2. Wierzbowski, M.; Filipiak, I.; Lyzwa, W. Polish energy policy 2050—An instrument to develop a diversified and sustainable electricity generation mix in coal-based energy system. Renew. Sustain. Energy Rev. 2017, 74, 51-70. [CrossRef]

3. Schmid, D.; Korkmaz, P.; Blesl, M.; Fahl, U.; Friedrich, R. Analyzing transformation pathways to a sustainable European energy system-Internalization of health damage costs caused by air pollution. Energy Strat. Rev. 2019, 26, 100417. [CrossRef]

4. Kirkerud, J.; Nagel, N.; Bolkesjø, T. The Role of Demand Response in the Future Renewable Northern European Energy System. Energy 2021, 235, 121336. [CrossRef]

5. Simoes, S.G.; Amorim, F.; Siggini, G.; Sessa, V.; Saint-Drenan, Y.-M.; Carvalho, S.; Mraihi, H.; Assoumou, E. Climate proofing the renewable electricity deployment in Europe-Introducing climate variability in large energy systems models. Energy Strat. Rev. 2021, 35, 100657. [CrossRef]

6. Potrč, S.; Čuček, L.; Martin, M.; Kravanja, Z. Sustainable renewable energy supply networks optimization-The gradual transition to a renewable energy system within the European Union by 2050. Renew. Sustain. Energy Rev. 2021, 146, 111186. [CrossRef] 
7. Market Regulation. EC Regulation EU 2019/943. 2019. Available online: https://www.consilium.europa.eu (accessed on 1 July 2021).

8. A Clean Planet for all. A European Strategic Long-Term Vision for a Prosperous, Modern, Competitive and Climate Neutral Economy. 2018. Available online: https:/ / ec.europa.eu/energy/sites/ener/files/documents/2_dgclima_rungemetzger.pdf (accessed on 1 July 2021).

9. URE Report. Report of the Energy Regulatory Office. 2020. Available online: https:/ /www.ure.gov.pl (accessed on 1 July 2021).

10. ENTSOE Report. 2021. Available online: https://transparency.entsoe.eu (accessed on 1 July 2021).

11. Brauers, H.; Oei, P.-Y. The political economy of coal in Poland: Drivers and barriers for a shift away from fossil fuels. Energy Policy 2020, 144, 111621. [CrossRef]

12. Lepszy, S. Analysis of the storage capacity and charging and discharging power in energy storage systems based on historical data on the day-ahead energy market in Poland. Energy 2020, 213, 118815. [CrossRef]

13. Lohrmann, A.; Child, M.; Breyer, C. Assessment of the water footprint for the European power sector during the transition towards a 100\% renewable energy system. Energy 2021, 233, 121098. [CrossRef]

14. PRSP. Plan Rozwoju Systemu Przesyłowego PSE z 2020 r. (Plan for the PSE Transmission System Development of 2020). 2020. Available online: https:/ / www.pse.pl/-/ plan-rozwoju-systemu-przesylowego-do-2030 (accessed on 1 July 2021).

15. Howaniec, N.; Smoliński, A.; Cempa-Balewicz, M. Experimental study on application of high temperature reactor excess heat in the process of coal and biomass co-gasification to hydrogen-rich gas. Energy 2015, 84, 455-461. [CrossRef]

16. Strategy for Responsible Development of 14 February 2016. Available online: www.gov.pl (accessed on 1 July 2021).

17. KPEiK. Krajowy Plan Energii i Klimatu, Wersja Złożona do KE, (National Plan for Energy and Climate, Version Submitted to the EC), Krajowy Plan na Rzecz Energii i Klimatu na Lata 2021-2030-Ministerstwo Klimatu i Środowiska. Available online: www.gov.pl (accessed on 1 July 2021).

18. Ruuska, I.; Ahola, T.; Artto, K.; Locatelli, G.; Mancini, M. A new governance approach for multi-firm projects: Lessons from Olkiluoto 3 and Flamanville 3 nuclear power plant projects. Int. J. Proj. Manag. 2011, 29, 647-660. [CrossRef]

19. Smyth, H.; Lecoeuvre, L.; Vaesken, P. Co-creation of value and the project context: Towards application on the case of Hinkley Point C Nuclear Power Station. Int. J. Proj. Manag. 2018, 36, 170-183. [CrossRef]

20. Zołotajkin, M.; Ciba, J.; Kluczka, J.; Skwira, M.; Smoliński, A. Exchangeable and Bioavailable Aluminium in the Mountain Forest Soil of Barania Góra Range (Silesian Beskids, Poland). Water Air Soil Pollut. 2010, 216, 571-580. [CrossRef] [PubMed]

21. Chećko, J.; Urych, T.; Magdziarczyk, M.; Smolinski, A. Research on the Processes of Injecting $\mathrm{CO}_{2}$ into Coal Seams with $\mathrm{CH}_{4}$ Recovery Using Horizontal Wells. Energies 2020, 13, 416. [CrossRef]

22. Smoliński, A.; Dombek, V.; Pertile, E.; Drobek, L.; Gogola, K.; Żechowska, S.W.; Magdziarczyk, M. An analysis of self-ignition of mine waste dumps in terms of environmental protection in industrial areas in Poland. Sci. Rep. 2021, 11, 1-10. [CrossRef] [PubMed]

23. Smoliński, A.; Howaniec, N.; Gąsior, R.; Polański, J.; Magdziarczyk, M. Hydrogen rich gas production through co-gasification of low rank coal, flotation concentrates and municipal refuse derived fuel. Energy 2021, 235, 121348. [CrossRef] 